\title{
Chlorination Reaction Behavior of Zircaloy-4 Hulls: A Preliminary Study on the Effect of the Oxidation Process on the Reaction Rate
}

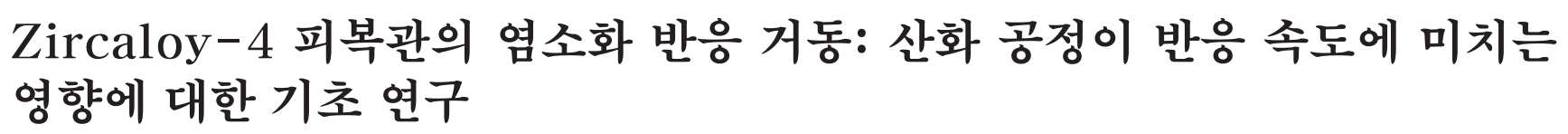
영향에 대한 기초 연구

Min Ku Jeon*, Chang Hwa Lee, Chul Min Heo, You Lee Lee, Yong Taek Choi, Kweon Ho Kang and Geun Il Park Korea Atomic Energy Research Institute, 989-111 Daedeokdaero, Yuseong-gu, Daejeon, Korea

전민구*, 이창화, 허철민, 이유리, 최용택, 강권호, 박근일

한국원자력연구원, 대전광역시 유성구 대덕대로 989-111

(Received January 07, 2013 / Revised February 12, 2013 / Approved February 13, 2013)

The recovery of Zr from Zircaloy-4 (Zry-4) cladding hulls was demonstrated to investigate the effect of the oxidation process on the reaction rate of the chlorination reaction. In chlorination reaction experiments performed for $6 \mathrm{~h}$, where reaction products were collected every $2 \mathrm{~h}$, it was observed that a significant decrease in the reaction rate was caused by the oxidation process $\left(500^{\circ} \mathrm{C}, 10 \mathrm{~h}\right.$ under an air atmosphere) within the reaction period of $0-2 \mathrm{~h}$. The amount of reaction residue increased from 0.95 to $1.65 \mathrm{wt} \%$ of initial weights in the fresh and Zry-500-10 (Zry-4 hulls oxidized at $500^{\circ} \mathrm{C}$ for $10 \mathrm{~h}$ under an air atmosphere) hulls, respectively. The purity of the recovered Zr was identical at $99.61 \mathrm{wt} \%$ for the fresh Zry-4 and Zry-500-10 hulls. Quantitative analysis of the chlorination reaction rate was performed by varying the reaction time from 0.5 to $1.0,2.0$, and $4.0 \mathrm{~h}$. The fitting results showed that the relationship between weight loss and reaction time can be interpreted by a linear line with a slope of $23.35 \mathrm{wt} \% / \mathrm{h}$ for the fresh Zry- 4 case, while two linear lines were necessary to fit the results of Zry-500-10. In addition, the slope values were 17.12 and $27.16 \mathrm{wt} \% / \mathrm{h}$ for $(0-20)$ and $(20-100)$ wt\% loss regions, respectively.

Key words: Hull waste, Chlorination reaction, Zr recovery, Pyroprocess, Reaction rate

본 연구에서는 산화 공정이 Zircaloy-4 (Zry-4) 피복관의 염소화 반응 속도에 미치는 영향을 연구하기 위하여 Zry-4 피복관 의 염소화 반응 실험을 수행하였다. 2 시간 마다 반응 생성물을 회수하며 총 6 시간 동안 염소화 반응 실험을 수행하였고, 이를 통해 500도에서 10 시간 동안 산화된 Zry-4의 경우 초기 0-2 시간 구간에서 반응 속도가 현저히 저하되는 것을 확인하였다. 반 응 잔류물은 fresh Zry-4와 산화된 Zry-4에서 각각 초기무게의 $0.95,1.65 \mathrm{wt} \%$ 로 확인되었다. 회수된 Zr의 순도는 두 경우 모 두 $99.61 \mathrm{wt} \%$ 로 동일하였다. 반응 속도의 정량적 분석을 위해 피복관의 반응 시간을 $0.5,1,2,4$ 시간인 경우에 대해 실험을 수행하였다. 실험 결과 분석을 통해 fresh Zry-4의 경우 전 영역에 걸쳐 $23.35 \mathrm{wt} \% / \mathrm{h}$ 의 단위 시간당 무게감소를 확인할 수 있 었고, 산화된 Zry-4의 경우 반응 속도가 두 영역으로 나뉘는 것을 확인하였다. 산화된 Zry-4의 무게 감소 속도는 0-20wt $\%$ 영 역에서는 $17.12 \mathrm{wt} \% / \mathrm{h}, 20-100 \mathrm{wt} \%$ 영역에서는 $27.16 \mathrm{wt} \% / \mathrm{h}$ 으로 나타났다.

중심단어: 피복관 폐기물, 염소화 반응, $\mathrm{Zr}$ 회수, 파이로프로세스, 반응 속도

*Corresponding Author. E-mail: minku@kaeri.re.kr, Tel: +82.42.868.2435 
Min Ku Jeon. et al : Chlorination Reaction Behavior of Zircaloy-4 Hulls: A Preliminary Study on the Effect of the Oxidation Process on the Reaction Rate

\section{Introduction}

The management of Spent Nuclear Fuel (SNF) is under intensive research in Korea, as the capacity of SNF storage pools at reactor sites is facing its limit. To solve this problem, KAERI (Korea Atomic Energy Research Institute) is developing a pyroprocess technique that employs electrochemical reactions instead of chemical reactions for a treatment of the SNFs [1-4]. The SNF consists of fuel material (fissionable material and fission products), cladding hull, and hardware waste, and the mass ratio of each component is about 100: 25: 5.7 [5]. It was also reported that the cladding hull waste generated during the wet reprocessing of SNF should be treated as Greater Than Class C (GTCC) waste or High Level Waste (HLW) $[5,6]$. In the case of the pyroprocess, it was suggested that the hull wastes generated during the pyroprocess needs further treatment to be recycled or disposed of as low level waste, owing to the residual SNF stuck on the inner surface of the hulls, the fission products (FPs) penetrated into the hulls, and the radioactivation of cladding hull constituents [6-8]. To minimize the amount of HLW generated during the pyroprocess, KAERI is developing a chlorination technique as a hull waste treatment method [8-12]. The chlorination method extracts $\mathrm{Zr}$, which consists of more than $97 \mathrm{wt} \%$ of $\mathrm{Zr}$ based cladding hull materials including Zircaloy and ZIRLO, by reacting $\mathrm{Zr}$ with $\mathrm{Cl}_{2}$ gas to produce gaseous $\mathrm{ZrCl}_{4}$. The low sublimation temperature of $\mathrm{ZrCl}_{4}\left(331^{\circ} \mathrm{C}\right)$ enables the easy separation of $\mathrm{ZrCl}_{4}$ from other constituent elements. The extraction of $\mathrm{Zr}$ can drastically reduce the amount of HLW owing to the high weight ratio of $\mathrm{Zr}$ in cladding hull waste.

Several reports were published on the treatment of cladding hull waste through the chlorination process [8-16]. As noted above, KAERI is working on a chlorination technique, and reported the fundamental calculation and experiment results [8-13]. The theoretical calculation results performed using the HSC chemistry code [17] revealed that the chlorination method is an efficient way to selectively recover $\mathrm{Zr}$ in the presence of residual SNF owing to the low sublimation temperature of $\mathrm{ZrCl}_{4}$ and high reactivity of $\mathrm{Zr}$ with $\mathrm{Cl}_{2}$ gas [9-11]. The experimental results showed that $\mathrm{Zr}$ of high purity (> 99.97wt\%) can be achieved via the chlorination reaction of Zircaloy-4 (Zry-4) hulls [11]. In addition, it was revealed that the chlorination technique can be employed for the oxidized Zry-4 hulls (at $500^{\circ} \mathrm{C}$ ), suggesting that the oxide layers generated during the oxidative decladding process cannot completely protect the hulls from the chlorination reaction [12]. Yasuike et al. [14] reported the successful separation of $\mathrm{Zr}$ from Zircaloy-2 hulls even in the presence of impurities including $\mathrm{Co}, \mathrm{U}, \mathrm{Ni}$, and $\mathrm{Cs}$. At the Oak Ridge National Laboratory, the feasibility of the chlorination technique was investigated in a hot cell, and a high decontamination factor of 1200 was achieved based on radiation dose of recovered $\operatorname{Zr}$ [15]. Bohe et al. [16] demonstrated a recovery of $\mathrm{Zr}$ from zircaloy shavings at temperatures between 220 and $450^{\circ} \mathrm{C}$, and it was shown that the chlorination reaction can be performed at temperatures as low as $220^{\circ} \mathrm{C}$. Although these results show some promise for the chlorination technique, intensive research should be performed including a scale-up, hot-cell demonstration, and reaction kinetics.

In this study, the chlorination reaction of Zry-4 hulls was investigated from a reaction rate point of view. The experiments were performed for fresh and oxidized Zry-4 hulls to simulate the effect of the oxidative decladding process on the reaction rate of the chlorination process.

\section{Experimental}

Before the reaction experiments, the hulls were cut into 3 $\mathrm{cm}$ long pieces. Some of the hulls were oxidized at $500^{\circ} \mathrm{C}$ for $10 \mathrm{~h}$ under an air atmosphere to verify the effect of the oxidative decladding process on reaction rate. The chlorination reaction was performed in a quartz reactor, which has a quart frit in the middle to support Zry-4 hulls and reaction residues while removing gaseous products from the heating zone. Reaction gas $\left(\mathrm{Ar}+\mathrm{Cl}_{2}\right)$ was fed from the top of the reactor and gaseous products were removed from the heating zone by passing through the quartz frit down to the bottom of the reactor. The flow of $\mathrm{Ar}$, unreacted $\mathrm{Cl}_{2}$ and gaseous reaction products pass through a collection zone where the temperature is kept at room temperature to collect $\mathrm{ZrCl}_{4}$ in its solid form while $\mathrm{Ar}$ and $\mathrm{Cl}_{2}$ are introduced to an exhaust treatment system. Detailed information on the reaction system is well described in our previous work [11]. 
All reaction experiments were performed at $380^{\circ} \mathrm{C}$.

Two types of experiments were performed in this study. First, fresh Zry-4 (without oxidation) and Zry-500-10 (Zry-4 oxidized at $500^{\circ} \mathrm{C}$ for $10 \mathrm{~h}$ under an air atmosphere) hulls were reacted with chlorine gas for $6 \mathrm{~h}$ while collecting reaction products every $2 \mathrm{~h}$. The reaction products were analyzed using an ICP-AES (Inductively Coupled Plasma - Atomic Emission Spectroscopy) system, while the reaction residues were analyzed using a SEM-EDS (Scanning Electron Microscopy - Energy Dispersive Spectroscopy) system owing to their high insolubility in acid solutions. A mixed gas of $\mathrm{Ar}$ and $\mathrm{Cl}_{2}$ was fed with a flow rate of $30 \mathrm{cc} /$ min for each gas. Second, the Zry-4 and Zry-500-10 hulls were reacted with chlorine gas for $0.5,1.0,2.0$, and $4.0 \mathrm{~h}$ to measure the chlorination reaction rate of the hulls. In this case, $\left(20 \mathrm{cc} / \mathrm{min} \mathrm{Ar}+10 \mathrm{cc} / \mathrm{min} \mathrm{Cl}_{2}\right)$ gas was employed as a reactant flow.

\section{Results and discussion}

Fig. 1 shows the chlorination reaction results performed for $6 \mathrm{~h}$ while collecting the reaction products every $2 \mathrm{~h}$. The properties (weight and composition) of the reaction products (recovered $\mathrm{ZrCl}_{4}$ ) and residues are listed in Table 1. In the pictures of the reactants (Fig. 1), a change in the colors of the Zry-4 hulls is clear: after the oxidization process (b), the hulls exhibited a light black color, while it was shiny metallic before the oxidation. In addition, it is interesting to compare the changes in the color of the reaction products with the increase in the reaction time. In both the fresh Zry-4 and Zry500-10 hulls, the color of the products changed from whitish orange $(0-2 \mathrm{~h})$ to brown $(4-6 \mathrm{~h})$. As it is known that $\mathrm{ZrCl}_{4}$ exhibits a white color, the changes in the color of the products suggest that the concentration of by-products (presumably Sn and iron chlorides) has increased with the reaction time. The composition analysis results shown in Table 1 support this assumption that the purity of $\mathrm{Zr}$ decreases with an increase in the reaction time although a quantitative correlation between the color of the reaction products and purity of recovered $\mathrm{Zr}$ is hard to achieve. The weight ratios of $\mathrm{Cr}$ and $\mathrm{Fe}$ significantly increased with the reaction time, while that of $\mathrm{Sn}$ was almost constant regardless of the reaction time. A summary of the properties of the reaction products (shown in Table 1) revealed that the overall reaction products exhibited a high Zr purity of $99.61 \mathrm{wt} \%$ for both the fresh Zry-4 and Zry-500-10 cases. The composition analysis results also showed that the high purity of $\mathrm{Zr}$ was originated from lower $\mathrm{Sn}$ and $\mathrm{Cr}$ contents in the reaction products when compared to the initial contents. Pre-

Table 1. Weight and composition measurement values of the reactants, reaction products, and residues employed for the chlorination reaction performed at $380^{\circ} \mathrm{C}$ for $6 \mathrm{~h}$ flowing $30 \mathrm{cc} / \mathrm{min} \mathrm{Ar}+30 \mathrm{cc} / \mathrm{min} \mathrm{Cl}_{2}$. Reaction products were collected every $2 \mathrm{~h}$

a) Compositions of the residues were measured using the SEM-EDS system.

\begin{tabular}{|c|c|c|c|c|c|}
\hline \multirow{2}{*}{ Fresh Zry-4 } & \multicolumn{4}{|c|}{ Composition (wt\%) } & \multirow{2}{*}{ Weight (g } \\
\hline & $\mathrm{Zr}$ & $\mathrm{Sn}$ & $\mathrm{Cr}$ & $\mathrm{Fe}$ & \\
\hline Reactant & 98.09 & 1.60 & 0.21 & 0.10 & 15.72 \\
\hline Product $(0-2 \mathrm{~h})$ & 99.77 & 0.18 & 0.05 & $\mathrm{~N} / \mathrm{D}$ & 17.86 \\
\hline Product $(2-4 h)$ & 99.54 & 0.18 & 0.08 & 0.21 & 15.84 \\
\hline Product $(4-6 h)$ & 97.93 & 0.20 & 0.13 & 1.73 & 0.98 \\
\hline Product total & 99.61 & 0.18 & 0.07 & 0.14 & 34.68 \\
\hline Residue $^{\mathrm{a}}$ & 88.30 & 1.83 & 9.87 & $\mathrm{~N} / \mathrm{D}$ & 0.15 \\
\hline Zry-500-10 & $\mathrm{Zr}$ & $\mathrm{Sn}$ & $\mathrm{Cr}$ & $\mathrm{Fe}$ & Weight (g) \\
\hline Reactant & 98.09 & 1.60 & 0.21 & 0.10 & 15.71 \\
\hline Product $(0-2 h)$ & 99.82 & 0.13 & 0.05 & $\mathrm{~N} / \mathrm{D}$ & 13.67 \\
\hline Product $(2-4 h)$ & 99.72 & 0.13 & 0.05 & 0.10 & 15.65 \\
\hline Product $(4-6 h)$ & 98.61 & 0.15 & 0.13 & 1.11 & 4.66 \\
\hline Product total & 99.61 & 0.13 & 0.06 & 0.20 & 33.98 \\
\hline Residue $^{a}$ & 93.51 & 1.09 & 5.02 & 0.38 & 0.26 \\
\hline
\end{tabular}


Min Ku Jeon. et al : Chlorination Reaction Behavior of Zircaloy-4 Hulls: A Preliminary Study on the Effect of the Oxidation Process on the Reaction Rate

(a)

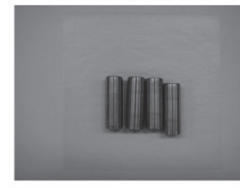

Reactant

(b)

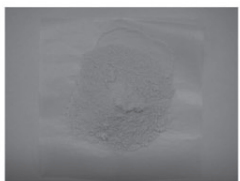

Reaction product $(0-2 \mathrm{~h})$

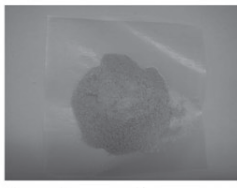

Reaction product (2 - 4 h)

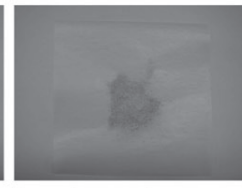

Reaction product (4-6h)

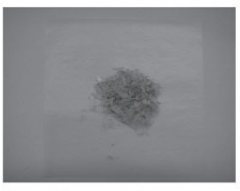

Reaction residue

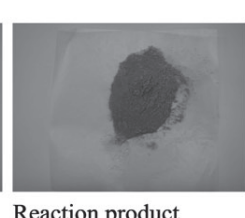

Reaction product (4-6h)

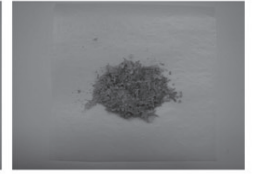

Reaction residue

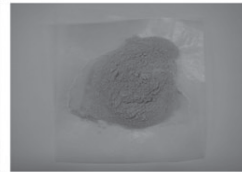

Reaction product $(2-4 h)$

Fig. 1. Pictures of the reactants, products, and residues of the (a) fresh Zry-4 and (b) Zry-500-10 samples performed at $380^{\circ} \mathrm{C}$ for $6 \mathrm{~h}$. A mixed gas of $30 \mathrm{cc} / \mathrm{min} \mathrm{Ar}+30 \mathrm{cc} / \mathrm{min} \mathrm{Cl} 2$ was fed as a reactant. The reaction products were collected for every $2 \mathrm{~h}$.

viously, it was suggested that the composition of $\mathrm{Cr}$ might be reduced after the chlorination process owing to a high boiling point (decomposition at $1300^{\circ} \mathrm{C}$ ) of $\mathrm{CrCl}_{3}$ [11]. But the detection of $\mathrm{Cr}$ in the reaction products suggests that volatile $\mathrm{Cr}$ chlorides such as $\mathrm{CrCl}_{4}$ [18] might have been produced during the chlorination reaction. In the case of $\mathrm{Fe}$, the content was not reduced after the chlorination reaction, presumably owing to a formation of volatile $\mathrm{FeCl}_{3}$. It should be mentioned that the Sn content was significantly reduced in the reaction products of both cases. Previously, it was suggested that $\mathrm{SnCl}_{4}(\mathrm{~g})$ is a preferred chloride form to be produced through the chlorination process [10], but the relatively low content of $\mathrm{Sn}$ in the reaction products needs further investigation. The properties of the reaction residues also need clarification, as it has been suggested that they might be managed as HLWs or GTCC wastes owing to the presence of residual SNF. As noted in Table 1, the weight ratios of the reaction residues were only 0.95 and $1.65 \mathrm{wt} \%$ of the initial values for the fresh Zry-4 and Zry-500-10 hulls, respectively, suggesting that the chlorination method is an efficient way to extract $\mathrm{Zr}$ from cladding hull waste. It should be discussed here that an increase in the amount of reaction residue was observed in the Zry-500-10 case. In our previous study [13], where an extraction of $\mathrm{Zr}$ from oxidized Zry-4 hulls was demonstrated at a $50 \mathrm{~g}$ scale, the amount of reaction residue was $0.95 \mathrm{wt} \%$, which is identical to the case of the fresh Zry-4 of the present study. Therefore, it is not reasonable to clarify a relationship between the oxidation process and the amount of reaction residue at this stage. However, it can be estimated that the amount of the reaction residues might range from 0.95 to $1.65 \mathrm{wt} \%$ of the initial weight whether the hulls were oxidized $\left(500^{\circ} \mathrm{C}, 10 \mathrm{~h}\right)$ or not. A compositional analysis of the reaction residues was performed using the SEM-EDS technique, the results of which are shown in Table 1. As expected from the ICP-AES results of the reaction products, the purity of the recovered $\mathrm{Zr}$ was reduced to 88.30 and $93.51 \mathrm{wt} \%$ in the fresh Zry-4 and Zry-500-10 hulls, respectively. It was also shown that the residues exhibit high $\mathrm{Cr}$ and $\mathrm{Sn}$ contents in accordance with the analysis results of the reaction products. A change in the weight of the reaction products should be discussed here; as clearly shown in Table 1 (and Fig. 1), the weight of the reaction products in each reaction period exhibits a different trend in the fresh Zry-4 and Zry-500-10 samples. In the period of a $0-2 \mathrm{~h}$ reaction, the fresh Zry- 4 hulls produced more products (17.86 g) than the Zry-500-10 hulls $(13.67 \mathrm{~g})$. On the other hand, only $0.98 \mathrm{~g}$ of the product was collected in the $4-6 \mathrm{~h}$ period for the fresh Zry-4 case, while $4.66 \mathrm{~g}$ was achieved for the Zry-500-10 hulls within the identical reaction time period. These results clearly show that the two cladding hulls have different reaction rates: the fresh Zry-4 hulls exhibit a higher reaction rate for the chlorination reaction than the Zry-500-10 hulls. Further investigation was performed to clarify the effect of the oxidation process on the chlorination reaction rate of Zry-4 hulls.

The reaction rate of the Zry-4 hulls was investigated by performing the chlorination reaction for 0.5, 1.0, 2.0, and $4.0 \mathrm{~h}$, and pictures of the reactants and reaction products 
are shown in Fig. 2 and 3 for the fresh and oxidized Zry-4 hulls, respectively. In the case of the fresh Zry-4 hulls (Fig. 2), the weight losses of the reactants were 11.59, 24.46, 48.06 , and $92.47 \mathrm{wt} \%$ after the chlorination reaction for 0.5 , 1.0, 2.0, and $4.0 \mathrm{~h}$, respectively. In the Zry-500-10 case (Fig. 3), the weight losses of the reactants were 8.95, 16.92, 42.14, and $96.46 \mathrm{wt} \%$ after $0.5,1.0,2.0$, and $4.0 \mathrm{~h}$ of the chlorination reaction, respectively. It should be noted that the weight loss of the fresh Zry-4 samples was higher than that of the Zry-500-10 samples for up to $2.0 \mathrm{~h}$, while it is reversed in $4.0 \mathrm{~h}$. The reaction time-weight loss relationship was evaluated by fitting the experimental results as shown in Fig. 4. A linear fit was employed for the results of the fresh Zry-4 hulls, resulting in a slope value of $23.35 \mathrm{wt} \% / \mathrm{h}$, while a linear fitting was not successful for the Zry-500-10 case. Recalling the results of the $6 \mathrm{~h}$ chlorination, which showed that the amount of the reaction product had a trend of Zry-4 > Zry-500-10 (0 - 2 h period), Zry-4 $\approx$ Zry-500-10 ( $2-4 \mathrm{~h}$ period), and Zry-4 < Zry-500-10 ( $4-6 \mathrm{~h}$ period), a fitting of the Zry-500-10 case was performed by employing two linear lines, resulting in two slope values of 17.12 and $27.16 w t \% / h$ for the $(0-20 w t \%$ loss) and (20 - 100wt\% loss) periods, respectively. The fitting results suggest that the oxide layer formed by the oxidation process works as a passivation layer resulting in a reduced reaction rate during an early stage of the reaction. However, at some point $(20 \mathrm{wt} \%$ (a)

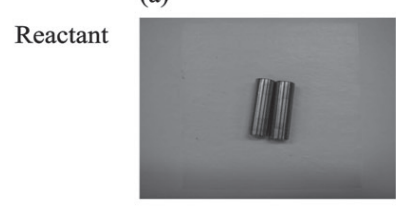

Product

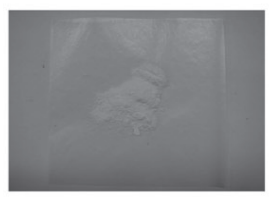

Residue

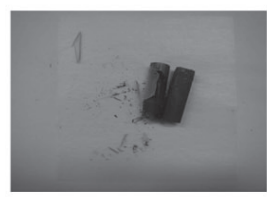

(b)
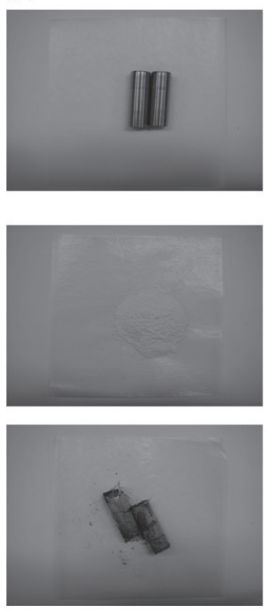

(c)
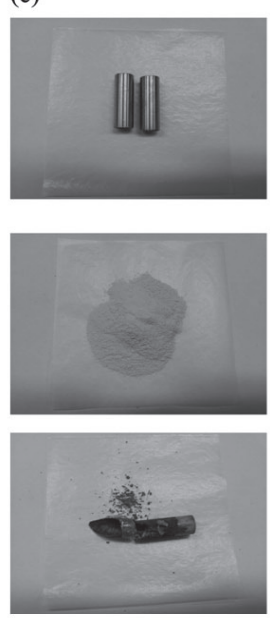

(d)
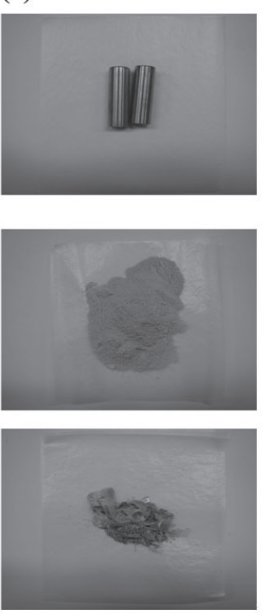

Fig. 2. The pictures of the reactants, products, and residues of the fresh Zry-4 hulls chlorinated for (a) $0.5 \mathrm{~h}$, (b) 1.0 $\mathrm{h}$, (c) $2.0 \mathrm{~h}$, and (d) $4.0 \mathrm{~h}$ at $380^{\circ} \mathrm{C}$. A mixed gas of $20 \mathrm{cc} / \mathrm{min} \mathrm{Ar}+10 \mathrm{cc} / \mathrm{min} \mathrm{Cl}_{2}$ was employed as a reactant.

(a)

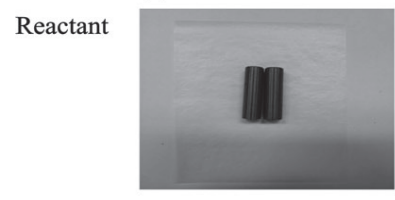

Product

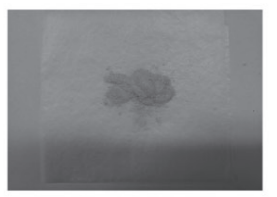

Residue

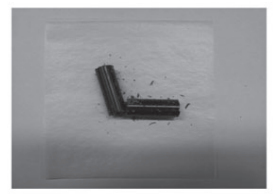

(b)
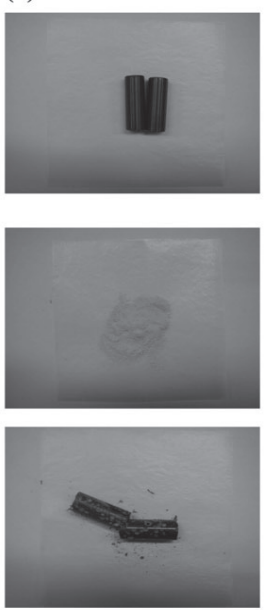

(c)
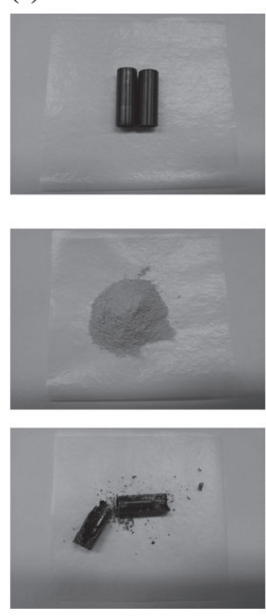

(d)
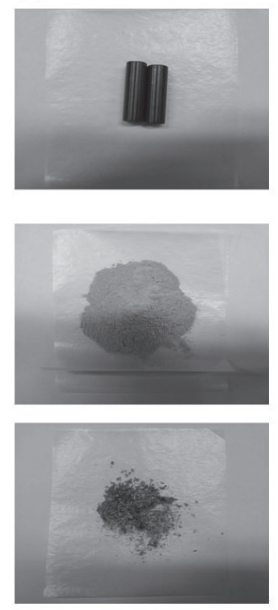

Fig. 3. The pictures of the reactants, products, and residues of the Zry-500-10 hulls chlorinated for (a) $0.5 \mathrm{~h}$, (b) 1.0 h, (c) $2.0 \mathrm{~h}$, and (d) $4.0 \mathrm{~h}$ at $380^{\circ} \mathrm{C}$. A mixed gas of $20 \mathrm{cc} / \mathrm{min} \mathrm{Ar}+10 \mathrm{cc} / \mathrm{min} \mathrm{Cl}_{2}$ was employed as a reactant. 
Min Ku Jeon. et al : Chlorination Reaction Behavior of Zircaloy-4 Hulls: A Preliminary Study on the Effect of the Oxidation Process on the Reaction Rate

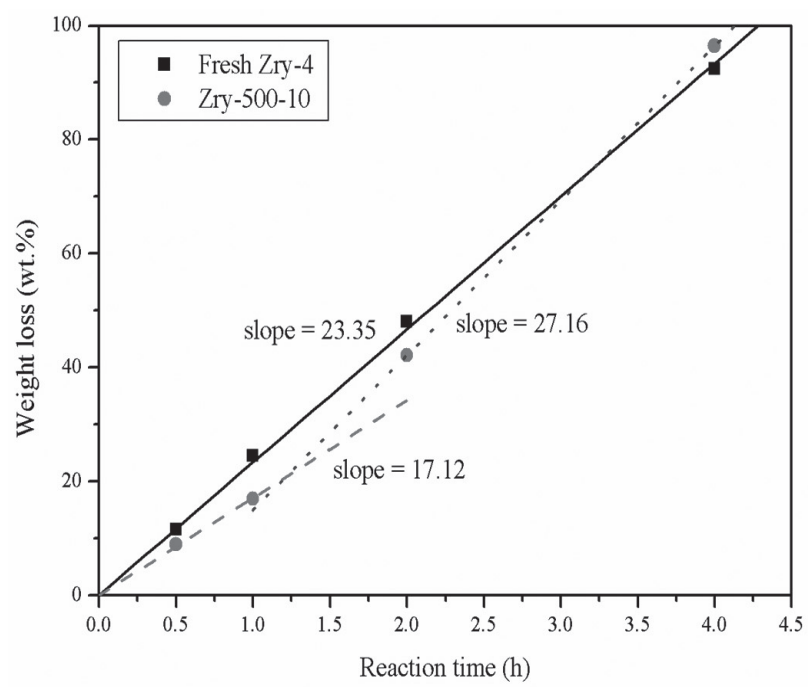

Fig. 4. The fitting results of the chlorination reaction results for the fresh Zry-4 and Zry-500-10 hulls.

loss in the present study), the effect of the oxidation layer is removed, and the hulls are chlorinated even faster than the fresh hulls. Although a quantitative analysis on the oxide layer-chlorination inhibition relationship is not clear at this point, these results clearly show that the oxide layer is one of the key parameters that determine the reaction rate of the chlorination reaction.

\section{Conclusions}

The effect of the oxidation process on the chlorination reaction rate of Zry-4 hulls was investigated. It was revealed that the oxidation process did not affect the purity of the recovered $\mathrm{Zr}$. Although an increase in the amount of the reaction residue was observed in the oxidized Zry-4 hulls, further investigation is essential to clarify a quantitative relationship between the oxidation process and the amount of the reaction residues. The reaction rate experiments showed that the weight loss of the fresh Zry-4 hulls caused by the chlorination reaction follows a linear fitting with a slope of $23.35 \mathrm{wt} \% / \mathrm{h}$, while two regions with slopes of 17.12 $(0-20 \mathrm{wt} \%$ loss region) and $27.16 \mathrm{wt} \% / \mathrm{h}(20-100 \mathrm{wt} \%$ loss region) were observed in the Zry-500-10 hulls. According to the reaction rate measurement results, it was concluded that the oxide layers formed during the oxidation process suppress the chlorination reaction during an early stage of about a $20 \mathrm{wt} \%$ loss.

\section{Acknowledgement}

This work was sponsored by the Nuclear R\&D Program of the Korean Ministry of Education, Science and Technology.

\section{REFERENCES}

[1] H. Lee, G.I. Park, K.H. Kang, J.M. Hur, J.G. Kim. D.H. Ahn, Y.Z. Cho and E.H. Kim, "Pyroprocessing technology development at KAERI", Nucl. Eng. Tech. 43(4), pp.317-328 (2011).

[2] K.C. Song, H. Lee, J.M. Hur, J.G. Kim, D.H. Ahn and Y.Z. Cho, "Status of pyroprocessing technology development in Korea”, Nucl. Eng. Tech. 42(2), pp.131-144 (2010).

[3] B.H. Park and W.I. Ko, "Nuclear Fuel Cycle Analysis Technology to Develop Advanced Nuclear Fuel Cycle", J. Korean Radioactive Waste Soc., 9(4), pp.219-230 (2011).

[4] J.H. Yoo, J.K. Kim, H.S. Lee, I.S. Seo and E. Kim, "Patent Analysis for Pyroprocessing of Spent Nuclear Fuel", J. Korean Radioactive Waste Soc., 9(4), pp.247-258 (2011).

[5] US-Japan Joint Nuclear Energy Action Plan Waste Management Working Group. Information basis for developing comprehensive waste management system, Fuel Cycle Research \& Development, FCR\&DUSED-2010-000051 (2010).

[6] T.S. Rudisill, "Decontamination of Zircaloy cladding hulls from spent nuclear fuel", J. Nucl. Mater. 385(1), pp.193-195 (2009).

[7] I.H. Jung, J.M. Shin, H.H. Lee, J.J. Park and M.S. Yang, "Investigation of PWR Hull with a View to Downgrade”, Sep. Sci. Tech. 41(10), pp.2097-2109 (2006).

[8] M.K. Jeon, C.J. Park, C.H. Lee, K.H. Kang and G.I. Park, "Simulation of radioactivation and chlorination reaction behavior for Zircaloy-4 and Zirlo cladding hull wastes", J. Radioanal. Nucl. Chem. 292(3), pp.1221-1228 (2012).

[9] M.K. Jeon, J.W. Lee, K.H. Kang, G.I. Park, C.H. 
Lee, J.H. Yang and C.M. Heo, "Simulation of chlorination reaction behavior of hull wastes by using the HSC code", J. Radioanal. Nucl. Chem., 289(2), pp.417-422 (2011).

[10] M.K. Jeon, K.H. Kang, G.I. Park and C.H. Lee, "Effect of chlorinating reagents on $\mathrm{Zr}$ recovery from Zircaloy-4 hull wastes: reaction behavior simulation by using the HSC code", J. Radioanal. Nucl. Chem., 292(1), pp.285-291 (2012).

[11] M.K. Jeon, K.H. Kang, G.I. Park and Y.S. Lee, "Chlorination reaction behavior of Zircaloy-4 hulls: experimental and theoretical approaches", J. Radioanal. Nucl. Chem., 292(2), pp.513-517 (2012).

[12] M.K. Jeon, K.H. Kang, C.M. Heo, J.H. Yang, C.H. Lee and G.I. Park, "Effect of oxidation conditions on chlorination reaction of Zircaloy-4 hulls", J. Nucl. Mater., 424(1-3), pp.153-157 (2012).

[13] M.K. Jeon, C.H. Lee, Y.L. Lee, Y.T. Choi, K.H. Kang and G.I. Park, "Demonstration of $\mathrm{Zr}$ recovery from $50 \mathrm{~g}$ scale Zircaloy-4 cladding hulls using a chlorination method", J. Korean Radioactive Waste Soc., 11(1), pp. 55-61 (2013).

[14] Y. Yasuike, S. Iwasa, K. Suzuki, H. Kobayashi, O. Amano and N. Sato, "Recycle of $\mathrm{Zr}$ metal from hull wastes by treatment of chlorination and metallization", Proc. ICEM'03: The 9th International Conference on Radioactive Waste Management and Environmental Remediation, ICEM03-4626, September 21-25, 2003, Oxford, England.

[15] E.D. Collins, G. D. DelCul, B.B. Spencer, R.R. Brunson, J.A. Johnson, D.S. Terekhov and N.V. Emmanuel, "Process Development Studies for Zirconium Recovery/Recycle from Used Nuclear Fuel Cladding", Proc. Chem., 7, pp.72-76 (2012).

[16] A.E. Bohe, J.J. Andrade Gamboa, E.M. Lopasso and D.M. Pasquevich, "Zirconium recovery from zircaloy shavings", J. Mater. Sci., 31(13), pp.34693474 (1996).

[17] A. Roine, Outokumpu HSC chemistry for windows, Pori, Finland (2002).

[18] L.N. Zelenina, Z.I. Semenova, V.A. Titov and T.P. Chusova, "Tensimetric investigation of the $\mathrm{CrCl}_{3}-\mathrm{Cl}_{2}$ system in the temperature range of $600-1200 \mathrm{~K}$ ",
Russ. Chem. Bull. Int. Ed., 53(8), pp.1621-1624 (2004). 